\title{
Geotourism Destinations - Visitor Impacts and Site Management Considerations
}

\author{
Ross K. Dowling / David Newsome ${ }^{2}$ \\ e-mail: r.dowling@ecu.edu.au \\ ${ }^{1}$ Edith Cowan University, Joondalup, Australia \\ ${ }^{2}$ Murdoch University, Murdoch, Australia \\ Dowling, R. K., \& Newsome, D. (2017). Geotourism Destinations - Visitor Impacts and Site Management Considerations. Czech \\ Journal of Tourism, 6(2), 111-129. DOI: 10.1515/cjot-2017-0006.
}

\begin{abstract}
Geotourism is becoming a well established form of tourism based on the geological environment. It offers a new form of sustainable tourism which is more holistic then previous niche forms of tourism. However, with more people than ever visiting natural areas worldwide, the cumulative impacts of visitors on geological sites is increasing. This paper surveys visitor impacts and site management at geological sites which are geotourism destinations. We describe geotourism which is the engine driving the core activities of conservation, education and sustainable development in geoparks. We then outline some lessons learned from management in dealing with visitor impacts at a heavily visited geopark in Taiwan, a volcano in Indonesia, and a coastal World Heritage site in England. The importance of education is emphasized for geo-climbing in Spain and all-terrain vehicles in Poland. A number of site management approaches are noted, including the importance of guiding as a management strategy as well as the value of a positive involvement by the local community. Finally, some examples are given of the risks associated with tourism activities in volcanic areas as well as related appropriate management activities.
\end{abstract}

\section{Keywords}

geotourism, geosites, UNESCO, impacts, destination management, sustainable development

JEL classification: Q26, L83 


\section{Introduction}

At a time when tourism across the world is growing significantly, the United Nations World Tourism Organization (UNWTO) declared 2017 to be the "International Year of Sustainable Development in Tourism". This fostered an even greater link between tourism development and natural environments. In 2016, there was 1,235 million international tourist arrivals worldwide and this grew by $6 \%$ in the first four months of 2017 compared to the same period the previous year (UNWTO, 2017a). One type of tourism which is growing around the world is geological tourism or "geotourism" (Dowling, 2013). Travel to areas of outstanding natural landscapes or unique landforms is not new, however, the concept of geotourism has only occurred in relatively recent times. It has been described as a form of tourism that specifically focuses on geology and landscape and can occur in either natural or human modified environments (Newsome \& Dowling, 2010). It is viewed as promoting tourism to geological sites (geosites), the conservation of geological diversity (geodiversity), and providing an understanding of earth sciences through appreciation and learning. This is achieved through independent visits to geological features, use of geological trails (geotrails) and view points, guided tours, geoactivities and patronage of geo-site visitor centres (Newsome, Dowling, \& Leung, 2012).

Along with this growth of tourism is the proportional additional pressures being placed on natural areas by the increasing number of tourists who are seeking activities and experiences in non-urban settings. Whilst many of these visitors will end up being more interested in the natural environment and feel some sense of stewardship for it, the potential remains for a range of adverse impacts on natural areas, especially where there are sites receiving high visitation. Some of these impacts will be biophysical and / or socio-cultural. Biophysical impacts caused by humans at geological sites include site modification, weathering, erosion and graffiti, as well as people undertaking activities that are not compatible with geotourism. Such impacts are occurring at many geotourism destinations and geological sites of international significance. The aim of this paper is to provide a focus and overview of geotourism occurring in UNESCO recognised and other internationally important sites of geological interest. It also outlines a range of possible negative impacts, provides an overview of visitor management strategies, and considers appropriate forms of development at sites of geological significance.

\section{Overview of geotourism}

Tourism is the commercial organization and operation of holidays and visits to places of interest. According to the United Nations World Tourism Organization (UNWTO), the large increase in international tourists produced 1 in 10 global jobs and $7 \%$ of the world's exports worth US\$1.4 trillion in 2016 (UNWTO, 2017b). Overall, tourism has grown faster than world trade during the past five years.

Essential to the development of geotourism is the understanding of the identity or character of a region or territory. To achieve this, geotourism is viewed as being based on the idea that the environment is made up of abiotic, biotic, and cultural components 
(Dowling, 2013). This approach comprises the abiotic elements of geology and climate, the biotic elements of animals (fauna) and plants (flora), and cultural or human components, both past and present. Geotourism "argues" that to fully understand and appreciate the environment, one must know about the abiotic elements of geology and climate first, as these determine the biotic elements of animals and plants which live there. By extension, the combination of these two components of the environment determine the cultural landscape of how people lived in the area in the past, as well as how they live there today. Thus, geotourism can be viewed as a spectrum which at one end is focussed exclusively on geology and landforms (Figure 1). This is a "geological focus" (e.g., Newsome \& Dowling, 2010) while at the other end of the spectrum, geology is seen as the basis for a more inclusive form of natural area tourism which is more holistic (e.g., National Geographic, 2017).

Figure 1 The Geotourism Spectrum

\begin{tabular}{|c|c|}
\hline \multicolumn{2}{|c|}{ The Geotourism Spectrum } \\
\hline \multicolumn{1}{|c|}{ Geotourism Viewed As } \\
$\begin{array}{c}\text { A Form or Type of Tourism } \\
\text { Geological Tourism }\end{array}$ & $\begin{array}{c}\text { An Approach to Tourism } \\
\text { Geographical Tourism } \\
\text { Includes Abiotic, Biotic \& Cultural } \\
\text { Elements }\end{array}$ \\
\hline
\end{tabular}

Source: own processing

Accordingly the essence of geotourism starts with an understanding of geology interpreted through its components of form (landforms and landscape), process (how the landforms originated), and time (when and how long these processes occurred). This constitutes the basis of a more holistic understanding of the environment and its component parts and thus provides the resident and tourist population with a greater connection to the environment in which they live or are visiting (Dowling, 2011).

Geotourism, especially via the geopark concept, is also a champion of sustainable tourism development by generating benefits for conservation (especially geo-conservation), appreciation (through geoheritage interpretation), and the economy (Dowling, 2015a). It has a primary focus on experiencing the earth's geological features in a way that fosters environmental and cultural understanding, appreciation and conservation, and is locally beneficial. Geotourism may be further described as having a number of essential characteristics. These elements combine to shape geotourism in its present form. It comprises a number of interrelated components all of which should be present for authentic geotourism to occur. Three principles are fundamental to geotourism: that it is geologically-based (based on the earth's geoheritage), sustainable (economically viable, 
community enhancing, and fosters geoconservation), and educative (achieved through geo-interpretation). All three characteristics are considered to be essential for a product to be considered an exemplar of geotourism.

An important part of geotourism is its specific interpretation of geoheritage consisting of the development of pre-visit and on-site pamphlets, viewpoint and geosite panels, self-guiding trails (supported by books, printed guides, marked points and panels), geological gardens, guided tours (e.g., cave tours, volcanic tours) and interpretive/visitor centres (comprising audio-visual content, interactive displays, collections of rocks, lectures, film shows). Increasingly important is the role of multimedia information on GPSsupported digital tours, utilizing smart phones and tablet computers (Dowling, 2015b).

Geotourism is now being used as a vehicle to foster sustainable tourism development in a number of regions around the world, for example, in China (Zhang et al., 2013), Malaysia (Ghani, Leman, \& Komoo, 2013), Philippines (Aquino, Schänzel, \& Hyde, 2017), Turkey (Citiroglu, Isik, \& Pulat, 2017), and Serbia (Began et al., 2017).

\section{UNESCO Global Geoparks}

A Geopark is a single, unified geographical area where sites and landscapes of international geological significance are managed with a holistic concept of protection, education and sustainable development (UNESCO, 2016). The Program commenced formally in 2004 following the 1st International Geoparks Conference in Beijing, China. Today, there are 127 Global Geoparks in 35 countries (UNESCO, 2017a). A Geopark uses its geological heritage, in connection with all other aspects of the area's natural and cultural heritage, to enhance awareness and understanding of key issues facing society, such as using our Earth's resources sustainably, mitigating the effects of climate change and reducing the impact of natural disasters. By raising awareness of the importance of the area's geological heritage in history and society today, Geoparks give local people a sense of pride in their region and strengthen their identification with the area. The creation of innovative local enterprises, new jobs and high quality training courses is stimulated as new sources of revenue are generated through geotourism, while at the same time the geological resources of the area are protected (UNESCO, 2016).

There are three levels of Geopark. The first is an Aspiring Geopark in which a community commences work on establishing a Geopark. At the next level the park becomes a National Geopark and joins the network of geoparks within its own country. The third level occurs when a National Geopark applies to UNESCO to join the Global Network. If successful, then it becomes a UNESCO Global Geopark (Figure 2). When this occurs, the Geopark is able to join a regional grouping such as the Asia Pacific Geoparks Network (APGN) or the European Geoparks Network (EGN). A UNESCO Global Geopark is given this designation for a period of four years after which the functioning and quality of each Geopark is re-examined during a revalidation process. 
Figure 2 The English Riviera UNESCO Global Geopark, United Kingdom
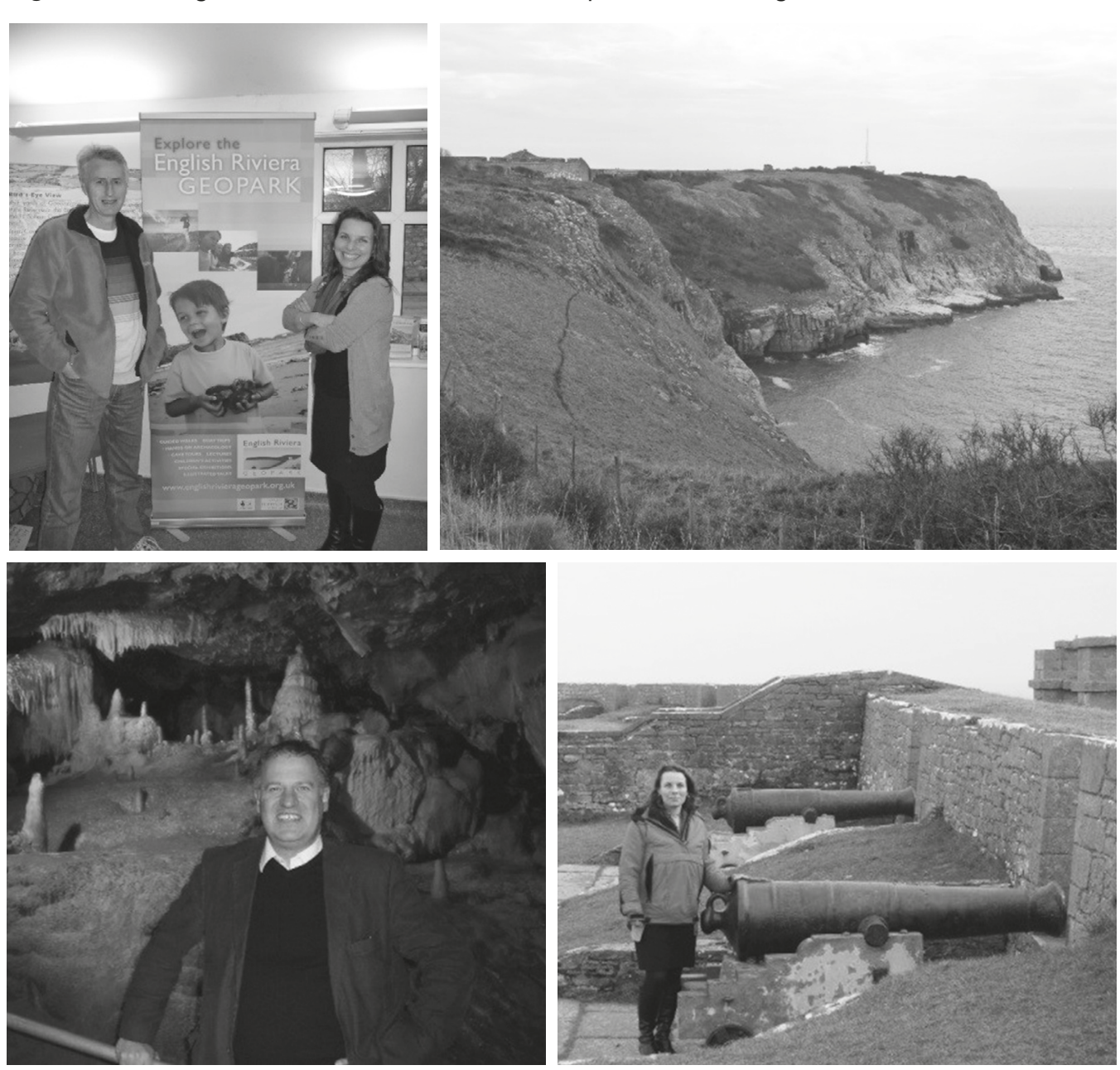

Upper Left: Ross Dowling with Melanie Border, Geopark Coordinator at the Seashore Centre, Paignton. Upper Right: The South Devon coastline, looking east, at Berry Head ANOB (Area of Outstanding Natural Beauty), Brixham. Lower Left: Nick Powe, Chair of the English Riviera Geopark organisation and Director of Kents Cavern Prehistoric Caves in Torquay, a major geotourism attraction in the Geopark. Lower Right: Melanie Border at the Berry Head Napoleonic fortifications, a cultural attraction.

Source: Ross Dowling

Geoparks empower local communities and give them the opportunity to develop cohesive partnerships with the common goal of promoting the area's significant geological processes, features, periods of time, historical themes linked to geology, or outstanding geological beauty. Just as importantly, the development of geoparks driven by geotourism encourages regional investment, creates new businesses and jobs, and generates financial benefits to regional communities. The UK National Commission for UNESCO 
estimated that the Global Geoparks Network in the UK had contributed £18.8M (AU\$33 M) to the economy in 2013 (UNESCO, 2014). In China a survey of eight geoparks showed that geotourism generated revenue tripled in the four year period from before to after their creation. In Yuntaishan Global Geopark geotourism was used to transform the economy of the Jiaozuo City region with geotourism related income increasing nearly 50 times over the 12 year period 2001 to 2012 from CNY0.6B $(\$ 1.189 \mathrm{M})$ to CNY25B 2012 (\$5B) (Ng, 2015).

Geoparks must demonstrate geological heritage of international significance and their purpose is to explore, develop and celebrate the links between that geological heritage and all other aspects of the area's natural, cultural and intangible heritages. UNESCO Global Geoparks give international recognition for sites that promote the importance and significance of protecting the Earth's geodiversity through actively engaging with the local communities.

The core activities of any Geopark are conservation, education and sustainable development through geotourism. Geoparks are areas that use the concept of sustainability, value the heritage of Earth and recognize the need to protect it (UNESCO, 2017b). The defining geological sites in UNESCO Global Geoparks are protected by indigenous, local, regional and/or national law and management authorities, in cooperation with the appropriate agencies, which allow for the necessary monitoring and maintenance of these sites. It is a prerequisite that all UNESCO Global Geoparks develop and operate educational activities for all ages to spread awareness of our geological heritage and its links to other aspects of our natural, cultural and intangible heritages. Geoparks also offer education, both formal and informal, for adults and retired people while many provide training for local people who can then, in turn, teach others.

\section{Understanding visitor impacts}

An understanding of the impacts of tourism at geological attractions is a releatively recent aspect of tourism study and now an on-going and evolving component of geotourism. Newsome et al. (2012) describe what possibly can be regarded as a worst case scenario, where heavy visitation is impacting on an iconic coastal geopark. Yehliu Geopark in Taiwan comprises upstanding landforms expressed as mushroom shaped sandstone rocks. Yehliu has become a mass tourism precinct attracting around 1.7 million visitors per annum. Heavy visitation is resulting in environmental impacts in the form of touching and climbing on landforms, congestion, accessing of restricted areas and the creation of informal trails. The site is managed in an attempt to prevent damage in the form of scraping and graffiti, accelerated erosion and also in an attempt to encourage visitor safety. Where pathways and boardwalks are present, they fail to contain visitors who tend to roam at random across the entire area of sandstone pinnacles. Only the well-recognised and marketed "Queens Head landform" is afforded full protection in the form of a guide (who supervises access for photography), a delineating ring of boulders, boardwalk for access and strategically placed security cameras (observation screens monitored in the visitor centre) which constantly monitor and 
record visitor activity. Even with such close scrutiny, visitor touching and scratching of the Queen Head still occurs, contributing to its active weathering rate of $2.3-2.5 \mathrm{~mm} /$ year at the "neck" area (Lin, 2008).

Lessons learned from the study show that the management of a site can be ineffective and can even lead to a management footprint that carries a significant impact in its own right (Figure 3). Management actions have resulted in the development of hardened walkways, viewing platforms, installation of educational materials, life saving equipment points, a boardwalk, barriers, extensive signage, security camera points and signed restricted areas. The end result is an overdevelopment scenario, in the form of a substantial management footprint, which fails to contain and even adds to negative impacts on the natural values of the site (Newsome et al., 2013). The presence of wardens does not prevent visitors climbing over the landforms and with an estimated 10,000 visitors in a single day, the congestion results in people straying from paths, not using the boardwalk and not adhering to park regulation specified "no-go" areas. The case illustrates that when there are large numbers of tourists, it is extremely difficult to effectively manage them.

Figure 3 Where pathways and boardwalks are present, they do not contain visitors who tend to roam at random across the entire area of sandstone pinnacles. Overall, the capacity to manage this site even on moderately busy days is very limited and much of the park is not effectively managed in terms of public access to landforms with people crossing nominated restricted access zones. Yehliu Geopark, Taiwan.

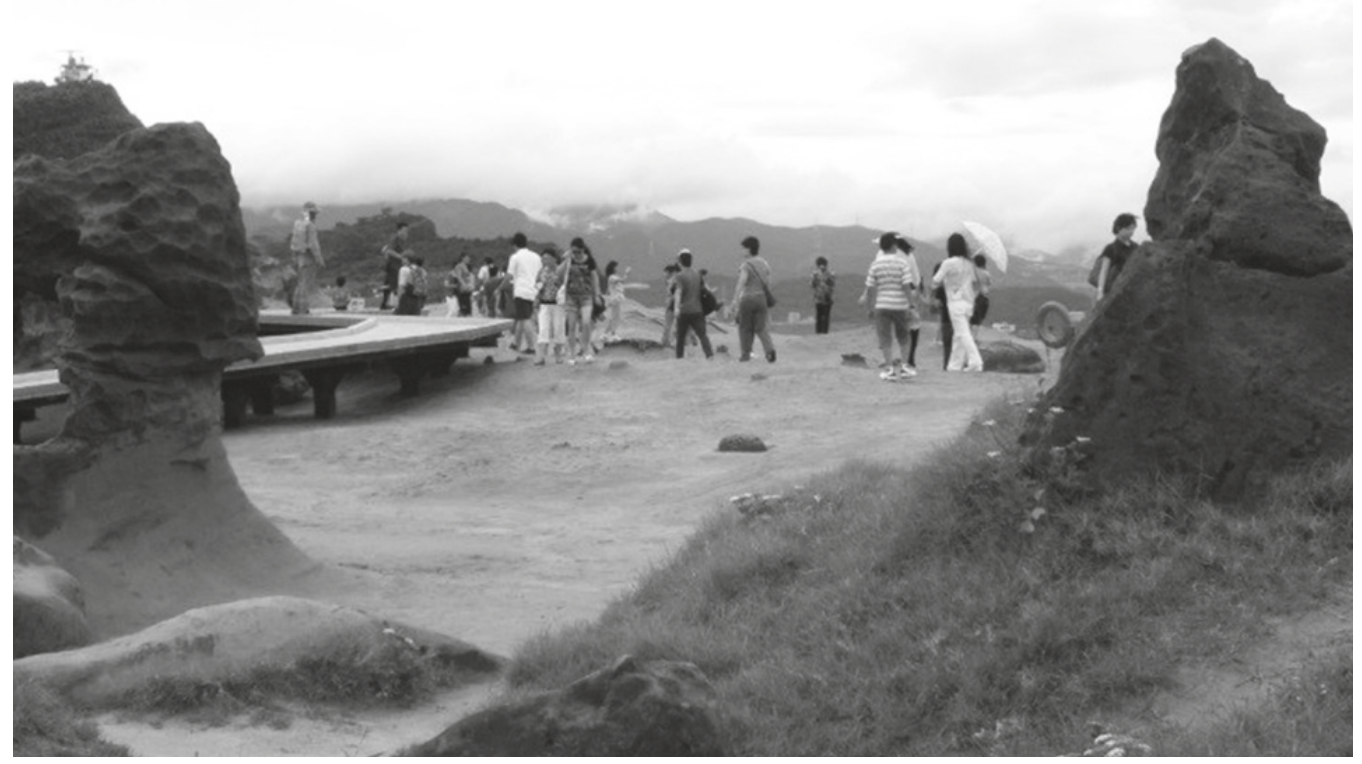

Source: David Newsome 
The visitor impact/management problems described at Yehliu are indicative of what can happen if sites become very popular and where there are no controls over tourism access and activities. The Yehliu case study is potentially applicable to many geoparks in China that currently receive heavy visitor pressure. Large numbers of vistitors are difficult to manage unless access is carefully controlled and there remains the risk of over development to cater for accommodation, facility and access demands.

Geological sites can become significantly degraded as a result of the cumulative impacts of visitation. One such example is Sibayak Volcano in Indonesia where there is significant access trail degradation, modification of the crater floor, graffiti, littering and summit trail proliferation. The lack of visitor guidelines and absence of interpretation to guide visitors can also be viewed as an additional negative impact (Newsome, 2010). The Sibayak Volcano example serves to point out that even naturally changing, and to all extents and purposes wild, geotourism destinations, can become degraded by heavy visitation. Visitor pressure is also exacerbated by a lack of site management, poor

Figure 4 Recreational beach access along the Jurassic Coastline World Heritage Area, England. Soft rocks, visible as bare areas, on the right side of the photo are easily eroded and access needs to be managed as illustrated by the constructed viewpoint and stairway located in the central part of the photograph. Informal (user created) trails are visible leading from the viewpoint illustrate the important point that visitor behaviour needs to be anticipated and managed accordingly.

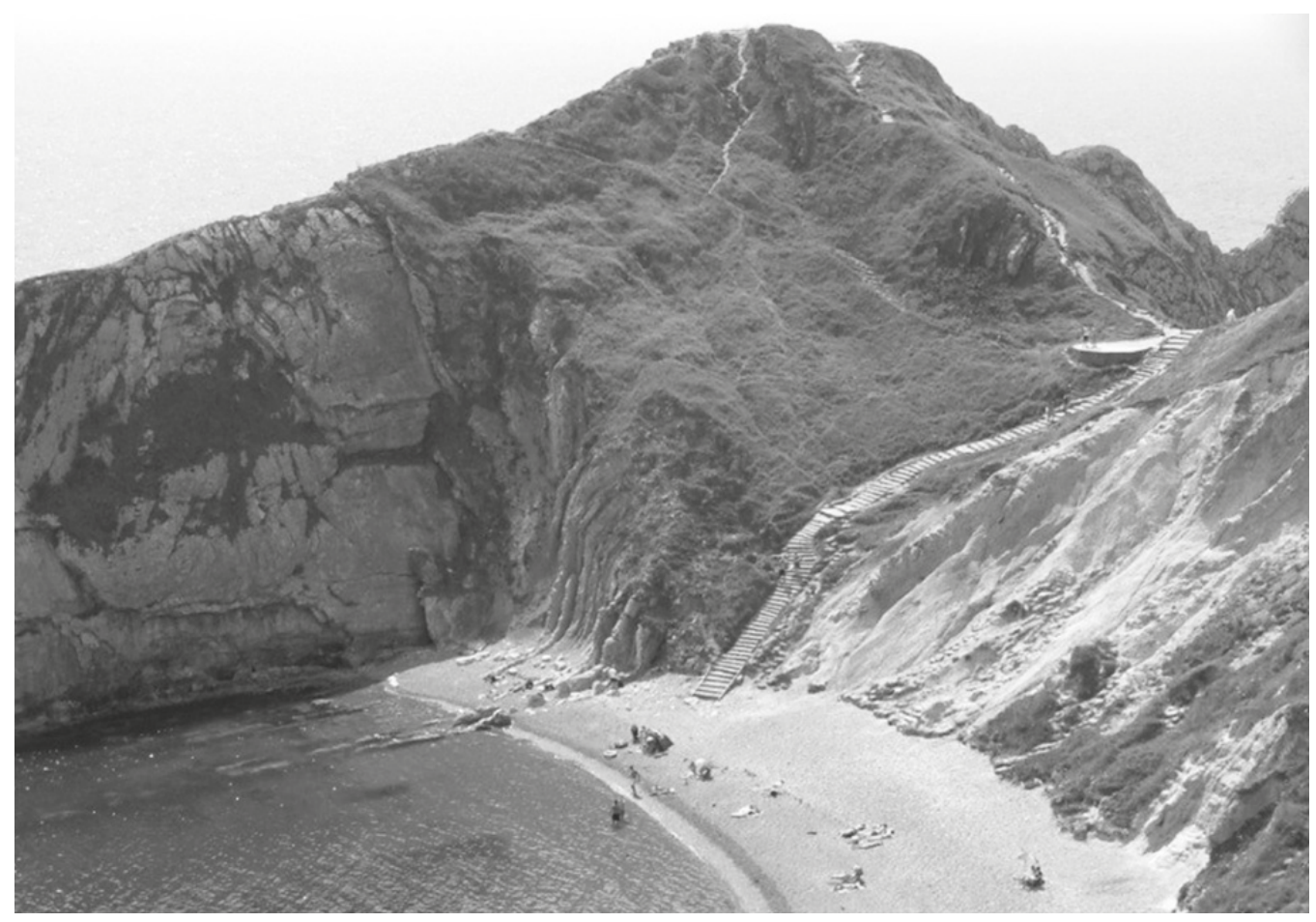

Source: David Newsome 
maintenance associated with an absence of monitoring, and an absence of appropriate education (Newsome, 2010; Newsome et al., 2012).

Although valued geotourism sites will vary in their susceptibility to damage even the hardest rocks will reflect some change, such as discolouration, when subjected to heavy visitation pressure. This can occur even under vigourous weathering conditions where rocks are changing naturally. Geological attractions and natural landscapes that comprise soft rocks (e.g., mudstones and friable sandstones) and/or unconsolidated regoliths will be more susceptible to trampling damage. Parts of the World Heritage Jurassic Coastine in southern England comprise friable and easily erodible rocks and such areas require designated access and visitor interpretation about the risks of visitor induced damage. Wealden sands and clays visible in Figure 4 are readily eroded under both natural and anthropogenic conditions and present as a hazard that requires tourism management in the form of controlled access. Although an access pathway, steps to the beach and a viewing platform are in place visitors have gone on to create informal trails (visible leading to the highest points of the landform, Figure 4). Such a scenario highlights the difficulty in containing recreation/tourism realted impacts where there is general recreational access for visitors.

It would seem that informal access to high points and beaches and climing/scambling on landforms is an issue that will continue to increase, possibly demanding more expensive control measures like controlled access and supervision in the form of guided touring and/or ranger presence.

Other niche types of geotourism can have adverse environmental impacts. For example, "geo-climbing" has been identified as a form of geotourism with a high educational component associated with contemplative sport, which affords the activity growing value in terms of accessibility and general connectivity (García-Rodríguez \& Fernández-Escalante, 2017). A case study of geoclimbing in the granite landscape of the La Pedriza (or La Pedriza del Manzanares), Spain, have made the area Spain's and arguably Europe's most prominent friction climbing training ground. Whilst the case study focuses on the geomorphological features and climbing routes, the authors note that overuse of the existing routes could be addressed by vesting geoclimbing with more environmental awareness through appropriate education.

Problems associated with motorised access have been described by Warowna et al. (2016). In a case study of a proposal for a Geopark in the Malopolska Vistula River Gap area of Poland, some gullies due to the uncontrolled development of motor tourism (quads and all-terrain vehicles) occurs causing damage to valley sides and floors and degradation of vegetation leading to accelerated erosion and deepening of trails. Measures to reduce this erosion have included the hardening of trails through the use of concrete slabs. However, this has lead to the degradation of geotourist values, such as landscape aesthetics, of these sites. Seven tourist trails associated with loess geoheritage have been planned for the region. All trails are provisionally located in the northern part of the planned Geopark owing to the occurrence of geosites of the highest value occurring there. Gullies and sunken lanes predominate on the proposed trails. The authors conclude that where under heavy tourist use the loess cover is susceptible to increased 
erosion, which 'poses a challenge to the sustainable development of tourism in future' (Warowna et al., 2016, p. 56). Thus, it is proposed to promote other trails in the general area which are currently not as well used in order to reduce such adverse impacts, and continual degradation, on trails subject to high usage.

The wider recreational demand on landscapes is also an important consideration in regard to the impacts of humans on geoheritage. Previously mentioned by Dowling and Newsome (2006), there is the increasing trend of natural areas, used as a backdrop for adventure related activities. Landfroms, such as rocky coastlines, cliffs, outcrops, dolines and caves are being increasingly used for a range of non-educational, human centrered activities placing some geosites at risk of degradation. Such activities include abseiling, hangliding, spelunking, adventure trials and sporting events., (e.g., Newsome \& Hughes, 2018).

\section{Managing visitors}

Site hardening, access trails, viewing facilities and educational signage and staff presence are all designed to minimise negative impacts and ensure visitor safety. At the same time, there are a number of visitor-management strategy related problems that are particularly common in popular protected areas in the East Asian region. These issues include overdeveloped infrastructure, substantial management footprint, on-going congestion and a failure to adequately control depreciative visitor behaviour (Leung, 2010; Newsome, 2010; Newsome et al., 2012).

While acknowledging the risks of over-development, controlling site access, explaining why controls are in place, managing visitor access, boardwalks and barriers, viewing platforms, site supervision via wardens, tour guides, rangers and remote technologies, have all proved to be successful strategies in managing geotourism. Educational approaches are vital in terms of engaging and value adding to tourist experiences. Fixed panels are a common passive educational tool and to be effective require regular monitoring and maintenance as degraded standing structures can negatively impact on visitor perceptions (Figure 5). While many techniques (e.g., electronic devices and media) are available to deliver educational content, it is direct face-to-face contact with guides that can deliver the most responsive, direct and varied content to visitors (Newsome et al., 2013).

\section{The importance of guiding as a management strategy}

The findings generated from a survey of visitors to Hong Kong Global Geopark, China, reveal that geopark visitors are willing to pay a price premium for higher quality geoguided tour services (Cheung, 2016). In particular, the "willingness to pay" (WTP) results suggest that geopark visitors are willing to pay an average of HK\$165.3 for an accredited geoguided tour, which is HK34.5 (26.4\%) more than their WTP for a non accredited geotour. This result implies that geopark visitors are willing to pay extra for the highquality geotour because they believe that they may receive higher quality and 
Figure 5 Dysfunctional interpretive panels located at high profile dinosaur fossil sites located in South Korea. Interpretive panels are only effective if there is adequate funding for the monitoring of weathering, storm damage and vandalism. Such situations can give visitors the impression of management neglect.

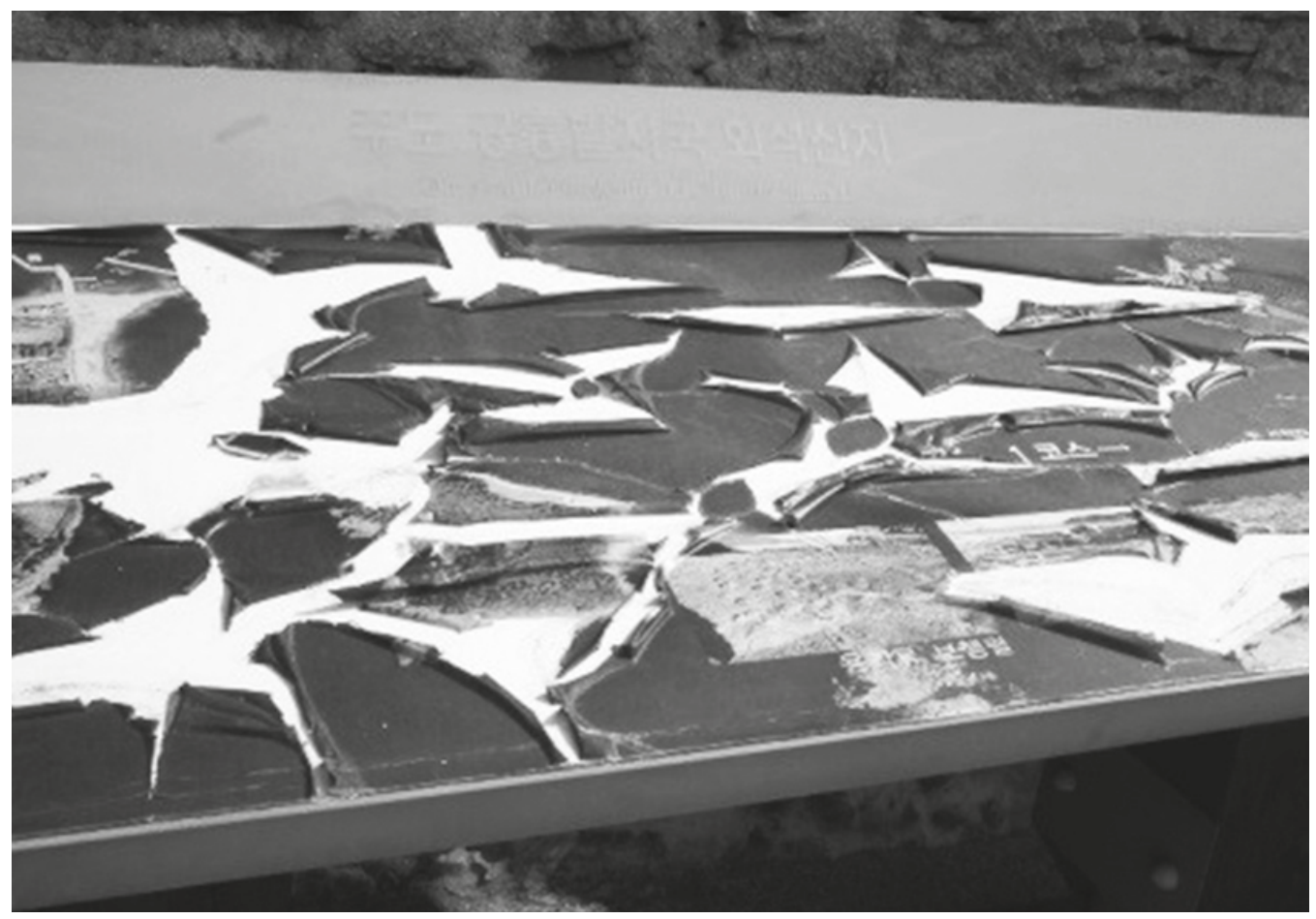

Source: David Newsome

more environmentally friendly services from well-trained accredited geotour guides. The results echo the positive perceptions of the geotour guide accreditation system in Hong Kong and the resulting expectations of receiving better services, including a professional interpretation of geological features, accurate geological knowledge and environmental consciousness.

As a subset of nature-based tourists, geotourists may exhibit different travel motivations in that they may be more influenced by the socio-psychological motivation to admire and enjoy the geopark than by intellectual curiosity about geological knowledge (Hurtado et al., 2014). However, the "escape factor", one of seven spacio-psychological push motivations (Crompton, 1979), was cited as the least important motive, which is similar to the findings for other nature-based tourists (Fung \& Jim, 2015a). The local community's lack of geological knowledge may explain these results given that geology has been neglected in the formal education curriculum in Hong Kong; thus, local residents generally lack relevant geological knowledge and find the topic difficult to understand (Fung \& Jim, 2015b). Local travellers in Hong Kong therefore generally do 
not aim to increase their geological knowledge through geotourism activities. In addition, Kerstetter et al. (2004) suggested that cultural differences between the East and the West may lead to the differences between Western and Asian tourists, such as the Asian pursuit of physical health being tied to the natural environment.

\section{The value of positive local community involvement}

Geotourism aims to foster tourism development opportunities while at the same time ensuring the conservation and/or protection of geoheritage attributes. Thus, geotourism's stakeholders are important as the real or perceived owners of geological features. These groups comprise the local host community and other community groups as well as the tourism industry, protected area managers, non-government conservation organisations, and the tourists themselves (Newsome et al., 2012). Tourists on geotours are interested in interacting with local communities as well as viewing landforms and other geological features. This occurs through viewing geo-attractions or participating in related activities such as undertaking self-guided or guided geotrail tours. Local guides are often especially highly valued by geotourists as they can provide an enhanced understanding of the surrounding abiotic, biotic and cultural environment (Mao, Robinson, \& Dowling, 2009).

Community involvement in tourism has increased due to its perceived local economic, social and conservation benefits (Figure 6). Geotourism development offers local residents income generation, jobs and skill development (Farsani et al., 2012). Thus, geotourism may be viewed as a way in which geology can be conserved and managed, largely through the efforts of local people and other stakeholders. In the development of geotourism there can be a number of stakeholders involved but with each holding a different perspective on the specifics of development. For example, community based geoheritage management projects may combine both the conservation and development aspects to varying degrees. Hull (2010), for example, highlights a number of planning and management efforts to promote the development of a sustainable tourism industry in Iceland by integrating geotourism into its overall destination development strategy based on a United Nations Development Programme (UNDP) framework. The five-year tourism development plan is being viewed as a tool of social and economic development and as a method of protecting the region's cultural and natural heritage.

\section{Risk assessment and management}

Calculating how to ameliorate risk is an evolving science (Ale, 2005). Such a science needs to be tempered by common sense, for example, in the face of active volcanic eruptions. Sometimes, regional area managers will need to make decisions which prohibit tourists from entering the affected area, whereas at other times, individual tourists will need to set their own limits.

Volcanoes are geotourism sites of particular significance as they attract tourists often on a mass scale. Where volcanoes are active, they pose a higher risk and require greater 
Figure 6 Naturtejo da Meseta Meridional UNESCO Global Geopark, Portugal is located in the centre of Portugal, near the border with Spain. Since its establishment in 2006, it has revitalised the interest of local people in their arts, crafts, music and culture. Here a group of local musicians and singers presents to an audience of participants from the 8th European Geoparks Conference in 2009.
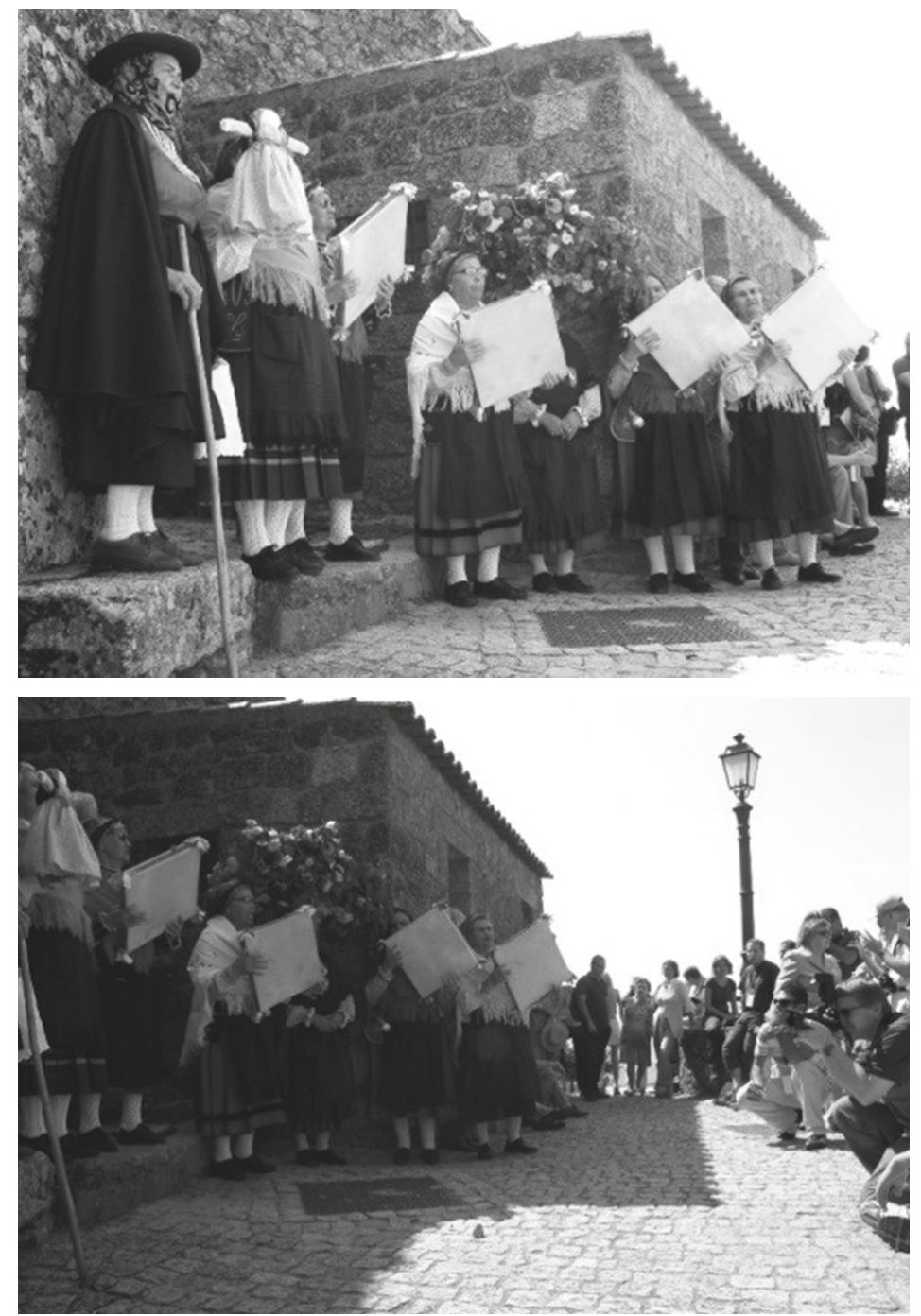

Source: Ross Dowling

management (Figure 7). Geosite managers of such volcanic areas must try to balance access and safety. Examples include safe, well-marked and fenced trails through areas of danger (e.g., hot springs), hiker registration, guides and communication devices for alerting tourists to signs of danger (Newhall, 2014). Climbing active volcanoes always comes with a certain risk. 
Figure 7 Volcanic eruption, Fernandina Island, Galapagos, April 2009. This impressive large-shield volcano has been erupting every four-five years, and its latest eruption was in April 2009. The eruption started off a radial fissure up in the slopes of the volcano and gradually the lava made it to the shoreline. The fissure was located about $14 \mathrm{~km}$ from the shoreline. As lava entered the water, a tremendous amount of water vapor was released, and provided the geotourists with an exciting experience.

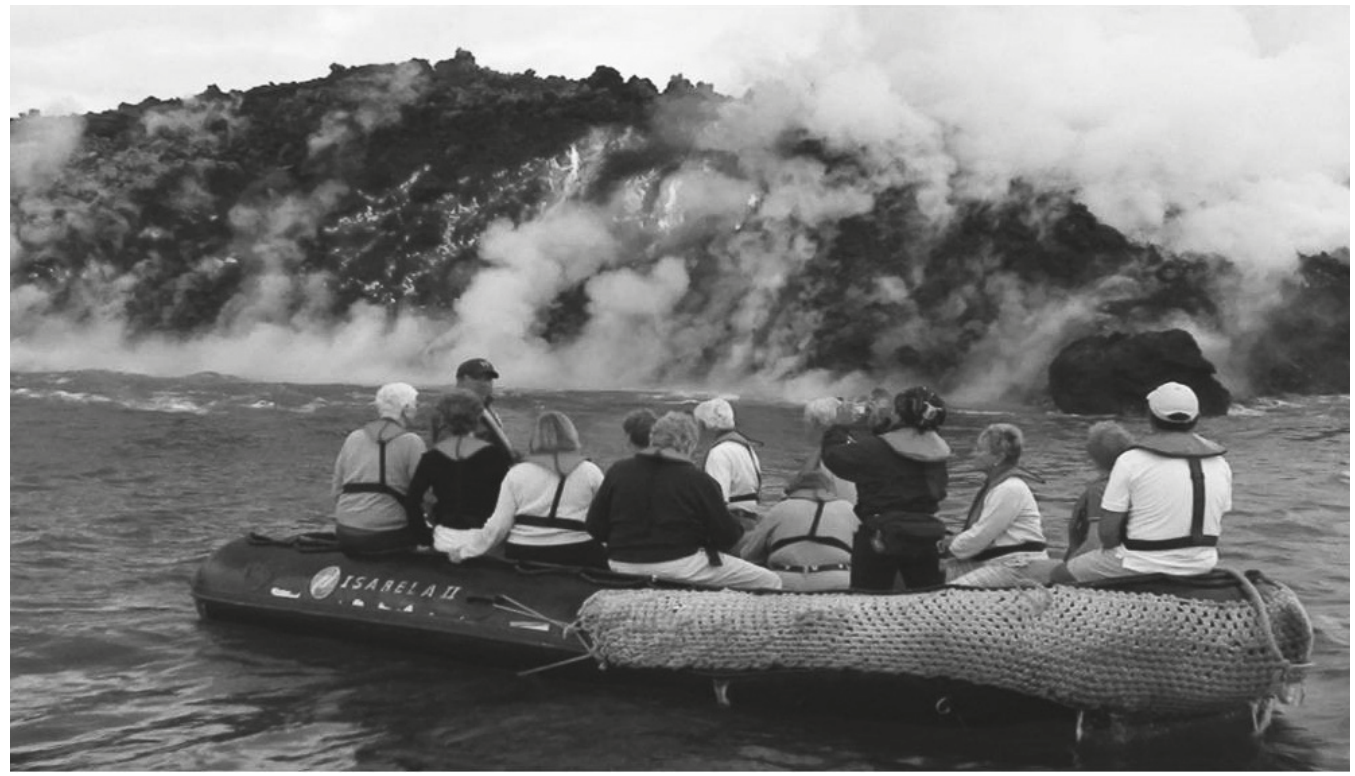

Source: Ramiro Jacome, Galapagos Naturalist, Metropolitan Touring, Ecuador

Iceland has a large number of volcano attractions, including its extensive volcanic landscape and geothermal activity (Dowling, 2010). Examples of volcanoes include Hekla, Katla and Grímsvötn which have high eruption frequencies and great volcanic productivity (Thordarson \& Larsen, 2007). Eyjafjallajökull also became world renowned in 2010 when an eruption sent tephra into the atmosphere, creating havoc for aircraft over Europe (Figure 8). Tourist activities in the southern region of the country include canyoning, ice and mountain hiking, horse riding, kayaking, mountain climbing, quad biking, snowmobiling, 4WD trips, and white water rafting (Bird \& Gísladóttir, 2014). Govermment agencies have developed a number of regional volcanic risk management strategies, including emergency response strategies. In 2008, the Icelandic Department of Civil Protection and Emergency Management prepared and distributed a brochure on Eruption Emergency Guidelines, which was published in six languages.

In Italy, Mt Vesuvius is particularly active, yet it represents one of the highest concentrations of a predominantly urban population in Europe (Karkut, 2010). In response to this, a National Emergency Plan for the Vesuvian Area (NEPVA) was produced in 1995. The plan is based around a model informed by the last major eruption in 1631 
Figure 8 Eyjafjallajökull is a volcano completely covered by an ice cap in Iceland. When it erupted in 2010, it caused enormous disruption to air travel across western and northern Europe over an initial period of six days. At that time, it was dubbed "the volcano that stopped the world". Since that time, it has become a major geotourism attraction which has spawned a local world class geo visitor centre.
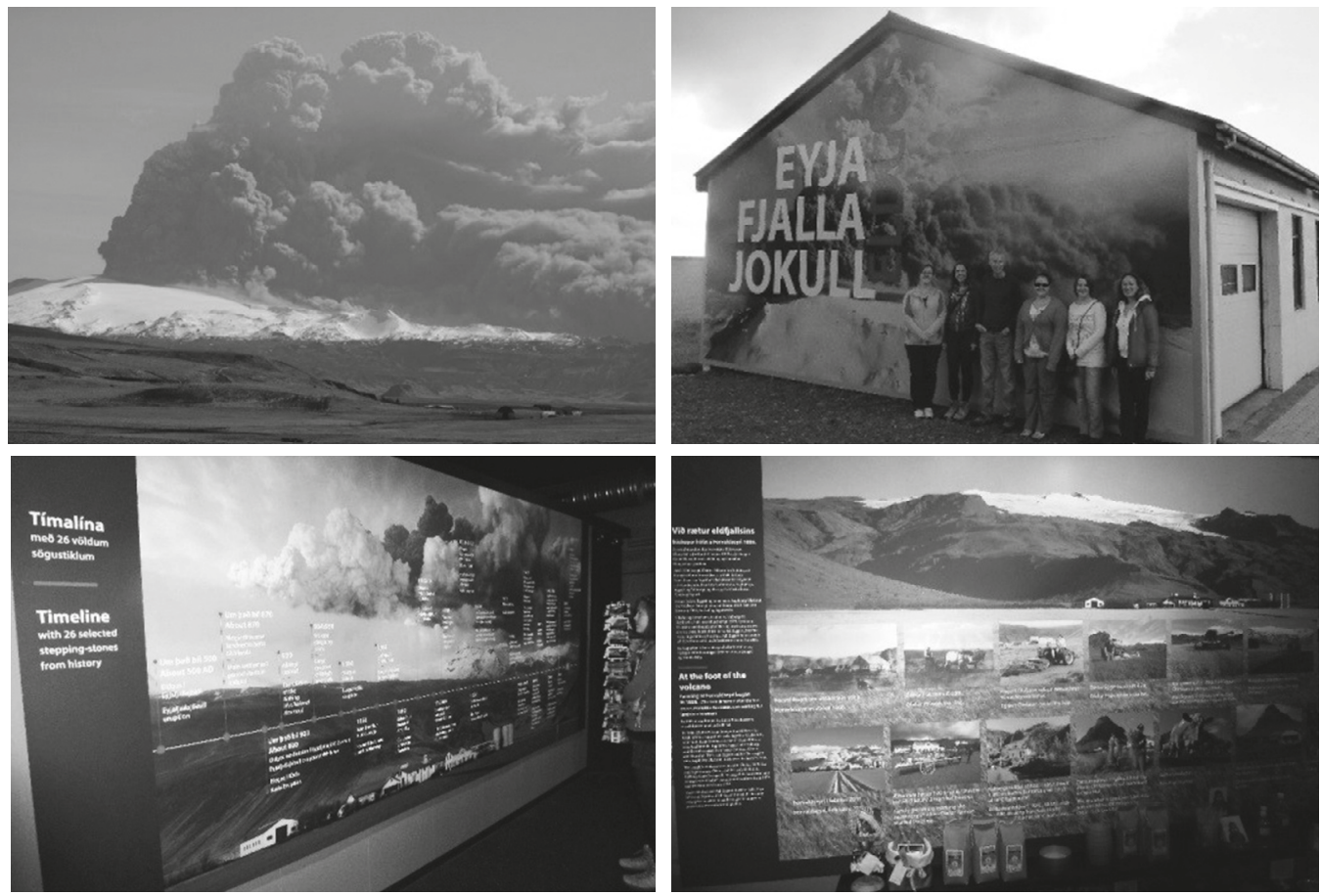

Upper Left: Eyjafjallajökull in eruption in 2010. Upper Right: The Eyjafjallajökull Eldgos Visitor Centre started by the local farmer's wife Guðný. Lower Left: The visitor centre has excellent geological interpretation throughout. Lower Right: It uses the geological knowledge to inform how living in the shadow of the volcano influences life in the region. Thus, it presents a more holistic geographic approach to geotourism which presents the relationships between its geological (Abiotic), plants and animals (Biotic) and how people live there today (Cultural) elements.

Source: Upper Left: Henrik Thorburn (Boaworm), Others: Ross Dowling

and assisted by computer generated maps outlining potential areas of hazard should the volcano erupt again. The Plan identifies three major hazard zones, the core of which is an inner "red zone" where tourists and residents would be immediately evacuated. Surrounding this zone is a "yellow zone" which would be vulnerable to pyroclastic fallout. A third outer "blue zone" was identified where it is anticipated that major floods and lahars may occur. Karkut (2010) concludes that in relation to developing tourism around active risk management and emergency evacuation plans must be implemented. To this end, the Vesuvius National Park Management in collaboration with the British Geological Society have published a series of educational pamphlets to explain the 
various geological phenomena. These can also be downloaded from the park's website in a range of languages.

\section{Conclusions}

Geotourism is emerging as a major niche form of tourism, largely but not solely, in natural areas. Allied to the increased interest in visiting geological features such as landforms and geology, is the attendant pressure placed on the sites visited with the increased risk of adverse environmental impacts. Whilst much tourism development at major geo-sites is developed and sustainably managed in an appropriate manner, this is not always the case. Therefore it has been argued that more needs to be done at geological sites subject to high visitation to ensure that highly valued geological features are not damaged. Examples of environmental damage includes visitors leaving designated trails, touching geo-features, adding graffiti on rocks and accelerating erosion at the site and surriounding areas.

As a response, appropriate management actions include the development of hardened walkways, viewing platforms, barriers and boardwalks; the availability of visitor guidelines, educational materials and interpretive signage; clearly designated restricted areas and where appropriate, the installation of security camera points. One general theme taken from the examples mentioned here is that there is a real need for supervision in the form of guided touring and/or ranger presence. It is suggested that while many techniques (e.g., electronic devices and media) are available to deliver interpretive content, it is direct face-to-face contact with guides that can deliver the most responsive, directed and varied content to visitors.

However, underpinning all of the above is the importance of developing any new or established geo-sites in an "appropriate manner". This is best carried out by undertaking extensive research and planning before development commences. This is done so that geological sites which will be opened up to tourists are examined in relation to their sustainable development, which incorporates conservation and community values. By doing this, the geological feature (attribute) can be protected and conserved whilst at the same time being opened up as a resource for tourists. In this way, such geological features can be utilised as an economic generator to provide funds for geoheritage protection along with economic benefits for the surrounding community. This then is true sustainable development with geological conservation and awareness for both tourists and local people alike. 


\section{References}

Ale, B. J. M. (2005). Tolerable or acceptable: Comparison of risk regulation in the United Kingdom and in the Netherlands. Risk Analysis, 25, 231-241.

Aquino, R. S., Schänzel, H. A., \& Hyde, K. F. (2017). Analysing push and pull motives for volcano tourism at Mount Pinatubo, Philippines. Geoheritage online DOI: 10.1007/s12371-017-0254-z.

Began, M., Višnić, T., Djokić, M., \& Vasiljevic, D. A. (2017). Interpretation possibilites of geoheritage in Southeastern Serbia-Gorge and canyon study. Geoheritage, 9, 237-249. DOI: 10.1007/ s12371-016-0197-9.

Bird, D. K., \& Gísladóttir, G. (2014). Southern Iceland: Volcanoes, tourism and volcanic risk reduction. In P. Erfurt-Cooper (Ed.), Volcanic Tourist Destinations (pp. 35-46). Berlin: Springer-Verlag. DOI: 10.1007/978-3-642-16191-9_2.

Cheung, L. T. O. (2016). The effect of geopark visitors' travel motivations on their willingness to pay for accredited geo-guided tours. Geoheritage, 8, 201-209. DOI: 10.1007/s12371-015-0154-z.

Citiroglu, H. K., Isik, S., \& Pulat, O. (2017). Utilizing the geological diversity for sustainable regional development, a case study - Zonguldak (NW Turkey). Geoheritage, 9, 211-223. DOI: 10.1007/ s12371-016-0196-x.

Crompton, J. L. (1979). Motivations for pleasure vacation. Annals of Tourism Research, 6, 408-424. DOI: 10.1016/0160-7383(79)90004-5.

Dowling, R., \& Newsome, D. (2006). Geotourism. Oxford: Elsevier Ltd.

Dowling, R. K. (2010). Emerging volcano and geothermal related tourism in Iceland. In P. ErfurtCooper \& M. Cooper (Eds.), Volcano and Geothermal Tourism: Sustainable geo-resources for leisure and recreation (pp. 209-220). London: Earthscan.

Dowling, R. K. (2011). Geotourism's global growth. Geoheritage, 3, 1-13. DOI: 10.1007/s12371010-0024-7.

Dowling, R. K. (2013). Global Geotourism - An emerging form of sustainable tourism. Czech Journal of Tourism, 2 (2), 59-79. DOI: 10.2478/cjot-2013-0004.

Dowling, R. K. (2015a). Geotourism. In J. Jafari \& H. Xiao (Eds.), Encyclopedia of Tourism. Berlin: Springer. DOI: 10.1007/978-3-319-01669-6_93-1.

Dowling, R. K. (2015b). Geotourism's contribution to sustainable tourism. In M. Hughes, D. Weaver, \& C. Pforr (Eds.), The Practice of Sustainable Tourism: Resolving the paradox (pp. 207-227). London: Routledge.

Farsani, N. T., Coelho, C., Costa, C., \& Neto de Carvalho, C. N. (2012). Geoparks and Geotourism: New approaches to sustainability for the $21^{\text {st }}$ century. Boca Raton, Florida, USA: Brown Walker Press.

Fung, C. K. W., \& Jim, C. Y. (2015a). Segmentation by motivation of Hong Kong Global Geopark visitors in relation to sustainable nature-based tourism. International Journal of Sustainable Development $\mathcal{E}$ World Ecology, 22, 76-88.

Fung, C. K. W., \& Jim, C. Y. (2015b). Unraveling Hong Kong Geopark experience with visitor-employed photography method. Applied Geography, 62, 301-313. DOI: 10.1016/j.apgeog.2015.05.014.

García-Rodríguez, M., \& Fernández-Escalante, E. (2017). Geo-Climbing and environmental education: The value of La Pedriza Granite Massif in the Sierra de Guadarrama National Park, Spain. Geoheritage, 9, 141-151. DOI: 10.1007/s12371-016-0187-y.

Ghani, K. A., Leman, M. S., \& Komoo, I. (2013). Sustainable tourism and geoparks. Paper presented at the Third Asia Pacific Geoparks Network Symposium, For the Innovation of the APGN. Jeju Island, South Korea, 7-13 September. 
Hull, J. S. (2010). Promoting geotourism: A case study from Northeast Iceland. In D. Newsome \& R. K. Dowling (Eds.), Geotourism: The Tourism of Geology and Landscape (pp. 61-76). Oxford, UK: Goodfellow Publishers.

Hurtado, H., Dowling, R. K., \& Sanders, D. (2014). An exploratory study to develop a geotourism typology model. International Journal of Tourism Research, 16, 608-613. DOI: 10.1002/jtr.1954.

Karkut, J. (2010). Under the volcano - can sustainable tourism development be balanced with risk management? In P. Erfurt-Cooper \& M. Cooper (Eds.), Volcano and Geothermal Tourism: Sustainable geo-resources for leisure and recreation (pp. 233-246). London: Earthscan.

Kerstetter, D. L., Hou, J. S., \& Lin, C. H. (2004). Profiling Taiwanese ecotourists using a behavioural approach. Tourism Management, 25, 491-498. DOI: 10.1016/S0261-5177(03)00119-5.

Leung, Y. F. (2010). Recreation ecology in East Asia: Redefining impact? In Y. C. Hsu (Ed.), Proceedings of the conference on the issues confronting the management of world's national parks, August 2010, Volume I (pp. 243-252). Taipei, Taiwan ROC: Hua Li Publishing.

Lin, Y. C. (2008). Evaluating the sustainability of accessible landscape area from the ecotourism perspective: A case study of Yehliu Geopark (in Chinese). Unpublished doctoral dissertation. Taipei, Taiwan ROC: National Taiwan Normal University.

Mao, I., Robinson, A. M., \& Dowling, R. K. (2009). Potential geotourists: An Australian case study. Journal of Tourism, 10(1), 71-80.

National Geographic. (2017). About Geotourism. Retrieved from https://www.nationalgeographic. $\mathrm{com} / \mathrm{maps} /$ geotourism/about.

Newhall, C. (2014). A dilemma for tourists and land managers alike: What risks to take? In Erfurt-Cooper, P. (Ed.), Volcanic Tourist Destinations (pp. 351-353). Berlin: Springer-Verlag. DOI: 10.1007/978-3-642-16191-9_27.

Newsome, D. (2010). The need for a planning framework to preserve the wilderness values of Sibayak Volcano, North Sumatra, Indonesia. In P. Erfurt-Cooper \& M. Cooper (Eds.), Volcano and Geothermal Tourism: Sustainable geo-resources for leisure and recreation (pp. 131-141). London, UK: Earthscan Publishing.

Newsome, D., \& Dowling, R. K. (Eds) (2010). Geotourism: The Tourism of Geology and Landscape. Oxford: Goodfellow Publishers.

Newsome, D., Dowling, R. K., \& Leung, Y. F. (2012). The nature and management of geotourism: A case study of two established iconic geotourism destinations. Tourism Management Perspectives, 2-3, 19-27. DOI: org/10.1016/j.tmp.2011.12.009.

Newsome, D., \& Hughes, M. (2018). The contemporary conservation reserve visitor phenomenon! Biodiversity and Conservation, 27, (2), 521-529. DOI 10.1007/s10531-017-1435-4.

Newsome, D., Moore, S. A., \& Dowling, R. K. (2013). Natural Area Tourism: Ecology, Impacts and Management, $2^{\text {nd }}$ edn. Bristol: Channel View Publications.

Ng, Y. (2015). Geoparks: A global approach to promote sustainable tourism for local communities. Paper presented at the Global Eco Asia Pacific Conference, Expanding Ecotourism Horizons. Rottnest Island, Australia, 17-19 November.

Thordarson, T., \& Larsen, G. (2007). Volcanism in Iceland in historical time: Volcano types, eruption styles and eruptive history. Journal of Geodynamics, 43(1), 118-152. DOI: org/10.1016/j. jog.2006.09.005.

UNESCO. (2014). Wider value of UNESCO to the UK. London: UK National Commission for UNESCO.

UNESCO. (2016). UNESCO Global Geoparks. Paris: UNESCO. 
UNESCO. (2017a). Eight geological sites in Asia, Europe and Latin America become UNESCO Global Geoparks. Paris: UNESCO Media Services News Release, 5 May.

UNESCO. (2017b). UNESCO Global Geoparks contributing to sustainable development goals. Paris: UNESCO.

UNWTO. (2017a). UNWTO Tourism Highlights, 2017 Edition. Madrid: United Nations World Tourism Organization.

UNWTO. (2017b). UNWTO World Tourism Barometer. Volume 15, June. Madrid: United Nations World Tourism Organization.

Warowna, J., Zgłobicki, W., Kołodynska-Gawrysiak, R., Gajek, G., Gawrysiak, L., \& Telecka, M. (2016). Geotourist values of loess geoheritage within the planned Geopark Małopolska Vistula River Gap, E Poland. Quaternary International, 399, 46-57. DOI: org/10.1016/j.quaint.2015.06.064.

Zhang, J., Tian, M., Wu, F., \& Mei, X. (2013). Discussion on key points of geopark construction and development in China. Paper presented at the Third Asia Pacific Geoparks Network Symposium, For the Innovation of the APGN. Jeju Island, South Korea, 7-13 September. 